\title{
The Rule of Law and the Litigation Process: The Paradox of Losing by Winning
}

\section{Catherine Albiston}

\begin{abstract}
This article expands upon the idea that repeat players influence the development of law by settling cases they are likely to lose and litigating cases they are likely to win. Through empirical analysis of judicial opinions interpreting the Family and Medical Leave Act, it shows how the rule-making opportunities in the litigation process affect the development of law and the judicial determination of statutory rights. In addition, the article explains how early judicial opinions might influence later judicial interpretations of the law. Although individuals may successfully mobilize the law to gain benefits in their disputes, that success often removes their experiences from the judicial determination of rights, limiting law's capacity to produce social change. This paradox of losing by winning separates the dispute resolution function of courts from their lawmaking function and raises questions about the legitimacy of law.
\end{abstract}

aw and society scholars increasingly question the capacity of law to produce social change. Despite landmark legal decisions and significant legislation, scholars point out that legal change produced little lasting improvement in the economic and social circumstances of the disadvantaged (Rosenberg 1991). The explanations are myriad and varied. Some argue that relying upon rights reinforces and legitimates an ideological legal system that masks inequality (Kairys 1982). They contend that legal rights not only maintain existing inequality, they also exact psychological costs from those who claim them (Bumiller 1988). Moreover, isolated legal victories can be easily dismantled without an organized and sustained effort toward change (Galanter 1974; Handler 1978). Some fault the structure and nature of courts, concluding that the institutional limitations of courts prevent achievement of lasting social change (Rosenberg 1991). They note the misleading nature of the "myth of rights": that ju-

I wish to thank Lauren Edelman, Kristin Luker, Marianne Constable, Howard Erlanger, David Lieberman, Gary Gold, Laura Beth Nielsen, Kaaryn Gustafson, Tom Scanlon, Marc Melnick, and the anonymous reviewers for their helpful and insightful comments. Address correspondence to Catherine Albiston, Jurisprudence and Social Policy Program, School of Law, University of California, 2240 Piedmont Ave., Berkeley, CA 94720 (e-mail: <ktalbiston@earthlink.net>). 
dicially affirmed rights are self-implementing instruments of social justice (Scheingold 1974). For most legal violations, the wronged party must mobilize his or her legal entitlement, which requires resources often unavailable to the intended beneficiaries of remedial statutes (Black 1973; Scheingold 1974). Not all scholars share this pessimism, recognizing the symbolic importance of law and the utility of law for organizing political or social movements (Williams 1991; McCann 1994). Some also recognize how law's subtle influence on the social interactions of everyday life creates the potential for social change (Engel \& Munger 1996). Scholars increasingly question, however, whether legal change alone can ensure lasting social consequences.

In his article "Why the 'Haves' Come Out Ahead: Speculations on the Limits of Legal Change," Marc Galanter suggests that the characteristics of parties also limit law's capacity to bring about social change. He argues that repeat players (RPs) shape the development of law by "playing for the rules": settling cases likely to produce precedent adverse to them and litigating cases likely to produce rules that promote their interests (Galanter 1974). By controlling the cases on which courts create the law, repeat players secure legal interpretations that favor their interests.

Galanter's significant insight suggests how the unequal resources and incentives of parties may allow repeat players to control the content of law and create precedent favorable to their interests. The strategic choices of parties between settlement and litigation, however, do not completely capture the complexity of litigation and how it shapes the development of law. Litigation is a process rather than a choice between two alternatives. Courts intervene in this process not only by encouraging settlement but also through intermediate decisions that may not entirely resolve a case. Indeed, although most cases settle, many do so after some sort of court intervention (Kritzer 1986). These points of intervention, like strategic settlement, also present opportunities to shape the developing law. The ways in which the litigation process and party-driven biases together might affect the evolving law have not been explored, however.

It should also be recognized that not all "law" is created in the same manner. Although Galanter's argument may make sense for judicially created common-law rules, his proposition deserves a closer look in the context of social reform legislation designed to address a social problem or protect the interests of the disadvantaged. Arguably, these remedial statutes strengthen the position of one-shot players (OS) relative to repeat players by transferring the rule advantage to the one-shot player. Thus, through one transaction, legislation may overcome the incremental legal advantages accumulated through strategic settlement behavior. Accordingly, at least in the early actions brought 
under a social reform statute, one might expect one-shot players to hold their own against repeat players.

On the other hand, legislation granting a new substantive right represents both the end of a long political struggle and the beginning of the battle for meaning in the courts (see Chayes 1976). The ultimate scope and power of these statutes depend not only on their language, but also on opinions generated by the common-law process of the judicial determination of rights in individual disputes. This interpretation process presents another opportunity for repeat players to "play for the rules" and influence the ultimate meaning of a statute.

In this article, I explore the litigation process in the context of employment litigation regarding the rights conferred by a federal employment statute, the Family and Medical Leave Act of 1993 (FMLA). I examine the pattern of adjudicated outcomes in published federal court opinions in the 5 years following the statute's enactment. By taking this recently enacted employment right as a subject, I explore the implications of Galanter's argument for the success or failure of legislated social change. In doing so, I elaborate the process of evolving law that Galanter describes and argue that not only the characteristics of parties but also the institutional features of the litigation process itself systematically influence the judicial determination of statutory civil rights.

I also contend that early published opinions regarding a civil rights statute often set the path of interpretation and the eventual scope and meaning of that statute. As judges review, synthesize, and extend each other's rulings through the system of judicial interpretation and precedent, they perpetuate patterns set early in the interpretation of a new law. Consequently the impact of strategic settlement and the litigation process on the shape of the law may matter most early in the life of social reform legislation.

Because each stage of the litigation process may influence the development of law, I look at the entire process of litigation, rather than focusing on outcomes in only one rule-making opportunity, such as appellate opinions. In addition, I examine the early published opinions regarding a single individual right, nationally recognized, at both the trial and appellate level, rather than comparing appellate opinions regarding disputes in diverse jurisdictions under many different laws (cf. Wheeler et al. 1987). By doing so, I examine Galanter's claims where one would most expect the law to protect the one-shot player: cases arising under a remedial statute granting individual rights.

I conclude that the perceived failure of remedial statutes to bring about social change flows in part from how the litigation process systematically obscures the substantive success of a new law. Although people may experience both success in litigation 
and significant social change as a result of a new civil right, this progress remains largely invisible in the common-law interpretation of that right. Over time, strategic settlement and the litigation process produce judicial interpretations of rights that favor repeat players' interests, limiting the scope and effectiveness of those rights. In the conclusion, I ask whether unequal access to the lawmaking function of courts undermines the legitimacy of the law.

\section{The Litigation Process and the Evolution of Legal Rules}

What forces shape the disputes that become the basis for judicial interpretations of the law? Although the life of the law has been experience (Holmes 1923), that experience is of a highly selective variety. Published judicial opinions in litigated cases capture only a small part of what goes on with regard to a new law. Not every violation of a statute results in a written judicial opinion interpreting that law. Courts do not automatically detect violations of law; they must depend for their caseloads on wronged parties mobilizing the law and bringing disputes to a legal forum (Black 1973). Unrecognized violations never reach a legal forum (Felstiner et al. 1981). Even individuals who recognize a harm sometimes decline to sue, instead "lumping it," or exiting from their relationship with the wrongdoer (Hirschman 1970; Galanter 1974; Miller \& Sarat 1981; Bumiller 1988). Some disputants mobilize the law beyond the view of courts by negotiating solutions "in the shadow of the law," with an eye toward the likely adjudicated outcome should the dispute ever reach a legal forum (Mnookin \& Kornhauser 1979). Others resolve their legally actionable differences through normative systems other than law (Macaulay 1963; Ellickson 1991). These violations and their resolution do not appear in published judicial interpretations of the law.

What is less obvious is that even violations that reach a legal forum do not necessarily result in a judicial interpretation of the law. It is well known, although often overlooked, that only a small fraction of disputes that reach court are adjudicated (Trubek et al. 1983; Maccoby \& Mnookin 1990). It is unlikely that adjudicated disputes are representative of all the disputes that arise under a remedial statute. Understanding how disputes are selected to become the basis of the judicial interpretations of the law provides some insight into whether the law reflects inequalities between the parties, as Galanter argues, as well as any biases present in the litigation process itself. The following sections explore two factors that influence the evolution of judicial interpretations of statutory rights: (1) strategic settlement by repeat players and (2) the nature and distribution of rule-making opportunities in the litigation process. 


\section{Settlement and Selection Bias}

Galanter's argument regarding how repeat players influence the evolution of law suggests that decisions to settle sometimes encompass factors beyond the circumstances of individual disputes. Several factors may influence parties' decisions to settle or litigate, including assessments of the likelihood of success, the costs of going forward, and the resources of the parties. Galanter (1974) argues, however, that repeat players have strategic interests beyond the monetary stakes of a particular dispute. Because repeat players expect to experience similar disputes in the future, generally have low stakes in the outcome of any one case, and often have the resources to pursue long-run interests, ${ }^{1}$ they

may be willing to trade off tangible gain in any one case for rule gain (or to minimize rule loss). We assume[ ] that the institutional facilities for litigation [are] overloaded and settlements [are] prevalent. We would then expect RPs to "settle" cases where they expected unfavorable rule outcomes. Since they expect to litigate again, RPs can select to adjudicate (or appeal) those cases which they regard as most likely to produce favorable rules. (Ibid., p. 101)

One-shot players who do not expect to litigate again are more likely to make the opposite trade-off-trading the possibility of making "good law" for tangible gain-because they may not value a favorable legal opinion for future disputes.

This process creates a selection bias in the "sample" of disputes presented for adjudication. Cases that settle drop out of the caseload on which judges interpret the law, shaping the circumstances under which legal questions arise. Strategic settlement influences the "selection" of cases presented for adjudication by tending to select cases in which the repeat player is more likely to win. Consequently, Galanter concludes, "we would expect the body of 'precedent' cases-that is, cases capable of influencing the outcome of future cases-to be relatively skewed toward those favorable to RP" (ibid., p. 102).

Some economic models investigating the effect of selective litigation on the efficiency of rules seem to confirm Galanter's analysis. These models indicate that where parties have asymmetrical future stakes, the choice for litigation over settlement will occur only where the odds for success favor the party with the greater future stakes, that is, the repeat player (Landes \& Posner 1979:273-74). Not only is litigation more likely in these circumstances, but the litigant with the greater future stakes will invest more resources into the litigation, and consequently is more likely to win (ibid., p. 279; Cooter \& Kornhauser 1980; Cooter 1996:1694). Thus, even if the collective benefit of the opposite rule is greater, rules favoring repeat players will survive because

1 Repeat players are often, but not always, organizations (Galanter 1975). 
one-shot opponents cannot capture the collective benefit to other one-shot players and thus have no incentive to represent their interests by refusing to settle (Cooter 1996:1693).

Galanter's typology of one-shot and repeat player litigants describes four possible pairings of parties: OS versus RP, OS versus OS, RP versus OS, and RP versus RP (Galanter 1975). Many remedial statutes, however, provide individuals with a private right of action against a larger, more powerful opponent (e.g., consumer rights against businesses or employment rights against employers). Consequently, rights created through remedial statutes typically involve one particular type of pairing, that of one-shot individual litigants suing repeat players, often organizations or institutions, for redress. As Wheeler et al. (1987) point out, in these circumstances, some of the advantages repeat player litigants enjoy come with the status of defendant, the typical position of repeat player litigants in legal actions regarding individual rights. ${ }^{2}$

Employment civil rights litigation can be conceptualized as presenting a classic instance of one-shot player versus repeat player litigation. ${ }^{3}$ Employers may consider not only the one-time costs of the outcome of a dispute, but also the future costs of an unfavorable rule. Employers have ongoing relationships with many employees; they must consider the possibility of being sued in the future. Even if they are never sued again, they still must continue to comply with employment laws. Adverse legal developments may increase employers' costs of complying with the law. Consequently, employers have a future stake in the interpretation of substantive provisions of employment laws.

Unlike employers, employees are unlikely to consider the future benefits of favorable rules because these benefits are collective, not individual. Few employees bring more than one employment-related lawsuit. Although they might benefit from a ruling protecting employees in their next job, they are unlikely to turn down an attractive settlement offer for the uncertain chance to preserve this nebulous benefit. Individual employees have little incentive to represent the collective interest of all employees in a

2 Indeed, it is difficult to differentiate repeat player status from either employer or defendant status in these circumstances. Employers are almost always organizations, which are likely to have the characteristics of repeat players (Galanter 1975). Remedial statutes are designed to provide rights to employees against their employers, rights that some less powerful employees could not negotiate privately. Accordingly, employers are generally defendants in these actions by definition. Defendant status is not necessarily determinative, however; other researchers have found that organizations tend to do better than individuals in litigation outcomes, regardless of whether they are the plaintiff or the defendant (ibid.; Songer \& Sheehan 1992).

3 Where a public interest organization or the government represents the plaintiff, these types of suits are more like repeat player versus repeat player litigation. Nevertheless, in every employment case there will be an employer, but there will not always be a public interest or government organization. It is also important to note that the FMLA only covers relatively large employers of 50 or more employees (29 U.S.C. $2611(4)$ ). 
favorable ruling because they cannot capture the collective benefit of an employee-friendly ruling to all employees who would be affected by the law. Thus, individual litigants will be likely to forgo rule gain for monetary gain in settlement negotiations.

This point does not mean that categorically, all employers have the characteristics of repeat players. Not all employers are large. Employers also vary in their legal sophistication; those that do business in competitive, high-stakes markets, for example, may have more experience with litigation and may retain more experienced counsel. Similarly, not all employees will necessarily behave as one-shot players. Some litigants may value vindication in court more than the prospect of monetary recovery and thus be less likely to forgo a judicial determination of their dispute for a settlement. In addition, those employees who belong to unions may have more bargaining power than nonunion employees and may receive legal assistance from the union.

In addition, sometimes repeat players appear on both sides of the litigation. Galanter suggests that changing the characteristics of one-shot parties to make them more like repeat players may reduce repeat players' advantage by offsetting the motivational and power imbalances between repeat players and oneshot players. For example, public interest organizations may better represent the collective interests of one-shot employee litigants than individual one-shot players and therefore be less likely to trade rule gain for monetary compensation (Galanter 1974). In addition, public interest organizations sometimes engage in strategic litigation to further social change and occasionally engage in strategic settlement themselves to avoid developing a negative legal precedent. ${ }^{4}$ Public interest representation may be more common in disputes arising under remedial statutes. In the employment context, government agencies such as the Equal Employment Opportunity Commission and the Department of Labor undertake litigation on behalf of employees from time to time. Some private, nonprofit organizations also represent employees in employment civil rights actions.

Public interest representation may have limitations, however. Government agencies that undertake civil rights litigation may settle cases for less than they are worth (Handler 1978:142). These "sweetheart" settlements may trade away both rule gain and monetary gain. In addition, even plaintiffs represented by public interest organizations still control their own cases. If a plaintiff wants to trade rule gain for monetary compensation but

4 The November 1997 settlement in Piscataway Township Bd. of Education v. Taxman, then before the Supreme Court, is one recent high-profile example of strategic settlement behavior by public interest organizations with long-term interests in protecting affirmative action. Taxman presented a challenge to affirmative action in an exceptional factual context where the decision to lay off a white teacher and retain a black teacher was made solely on the basis of race. The teachers had the same qualifications and had been hired on the same day. See Taxman $v$. Board of Education (1996). 
the public interest organization does not, a conflict of interest arises between the client and the public interest attorney. In these circumstances, repeat players can defeat the social change objectives of the public interest organization by offering the plaintiff a substantial sum for his or her damages while refusing to pay legal fees. ${ }^{5}$ This kind of offer induces settlement while simultaneously damaging the public interest organization's ability to undertake future litigation, as public interest organizations often depend on the fees generated from successful litigation to continue their activities.

Despite these qualifications, as a rough approximation an employer is more likely than an individual employee to have the characteristics of a repeat player, particularly in litigation under the FMLA. Only employers with 50 or more employees are covered under the FMLA; smaller employers are not defendants in the data reported here. Employers of this size are organizations; employees generally are not, with the rare exception of union or public interest representation. Only about $16 \%$ of workers are covered by collective bargaining agreements, however, and unions do not routinely undertake representation in statutory employment claims, as opposed to disputes arising under collective bargaining agreements. ${ }^{6}$ In addition, at least in the data reported here, public interest representation is rare. Accordingly, in employment disputes one would expect that employers generally have the characteristics of repeat players, whereas employees generally do not.

In employment cases, defendants have other incentives, in addition to the incentive to avoid rule loss, to settle cases they are likely to lose. For example, settlement allows employers to control the terms and conditions of the resolution of the dispute, including confidentiality. Employers may settle potential "losers" because a public victory could encourage their other disgruntled employees to sue. Employers who settle cases they expect to lose

5 See Evans v. Jeff D.(1985). In Jeff D., Idaho Legal Aid represented a class of children with emotional and mental handicaps seeking injunctive relief to cure deficiencies in both the educational programs and health care services provided to such children who are under state care. The state offered to settle the case by agreeing to all the injunctive relief requested by the plaintiffs, but refusing to pay any costs or fees associated with bringing the lawsuit. This offer created a conflict of in terest between Idaho Legal Aid and its clients. The attorney in question felt ethically bound to protect the interests of the clients by accepting the offer, but made the waiver of costs and fees conditional upon approval by the District Court (ibid., p. 722). The Court of Appeals invalidated the fee waiver and the case came before the Supreme Court, where Idaho Legal Aid argued that this type of settlement offer "exploits the ethical obligation of plaintiffs' counsel to recommend settlement in order to avoid defendant's statutory liability for its opponents' fees and costs" (ibid., p. 729). The Court upheld the fee waiver, noting that "a general proscription against negotiated waiver of attorney's fees in exchange for settlement on the merits would itself impede vindication of civil rights . . . by reducing the attractiveness of settlement" (ibid., p. 732).

6 U.S. Bureau of the Census (1997), Table 688. Approximately $43 \%$ of public sector workers are covered by union contracts, but only $11 \%$ of private sector workers are covered by union contracts (ibid.). 
also avoid the risk of unpredictable damage awards by a jury and in some cases can control dissemination of information about the settlement itself. For example, confidentiality clauses are common in employment settlement agreements. Agreements typically state that the employer denies liability and prohibit disclosing the amount of the settlement, particularly to the employers' current employees. Some also prohibit the plaintiff from publicly announcing the settlement or, in some circumstances, from discussing the factual allegations underlying the dispute. These restrictions sometimes also extend to attorneys representing the plaintiff.

Settlement prior to an adjudicated loss also serves the interests of another repeat player in employment litigation, counsel for the employer. Employers may retain a particular firm to represent them in employment disputes and advise them on compliance matters. Settling a losing case avoids a clear-cut defeat that might damage the firm's relationship with the client and prompt the client to find other representation in the future. Also, the employer may pay more for settlement once the judge rules in the employee's favor on liability, an outcome counsel may want to avoid. ${ }^{7}$

What does this analysis suggest about the development of a remedial employment statute like the FMLA? Although remedial employment statutes give the rule advantage to the employee, repeat player employers may still settle cases they expect to lose and litigate those they expect to win, ensuring that judicial interpretations of the statute occur in cases with the odds in their favor. If repeat players engage in this strategic behavior, Galanter's analysis predicts that judicial opinions will develop a pattern in which repeat players consistently win. Public interest representation of employees may mitigate this pattern, but on balance, one would predict that over time published judicial opinions interpreting the scope and meaning of a remedial employment statute would come to favor employers.

\section{Rule-Making Opportunities in the Litigation Process}

Although models of legal evolution typically describe the development of law as a result of a binary decision to settle or go to trial (Landes \& Posner 1979; Priest \& Klein 1984), strategic settlement alone does not capture how the litigation process influences the evolution of law. Very few cases go to trial; many more resolve at some point before trial, often after some kind of court decision or action (Kritzer 1986). Thus, legal evolution depends

7 Like most disputes, employment cases typically break down into the issues of liability and damages. Consequently, a judge may establish liability on a plaintiff's motion for summary judgment, for example, while leaving the ultimate question of damages for trial, although most cases settle at this point. Once liability is established, the settlement value of the case increases significantly due to the removal of any uncertainty about recovery. 
in part on when in the litigation process a case settles and how it is resolved if it does not. Modeling litigation as the choice between settlement and trial overlooks complexities of the litigation process itself that may create selection bias in the evolution of legal rules.

Litigation is not a one-time choice between trial and settlement. It is a temporally organized process with both rule-making and settlement opportunities along the way. For purposes of this article, by "rule-making opportunities" I mean points in the litigation process that may produce published judicial opinions containing substantive interpretations of a statute. That is, I assume that judges create and shape legal rules through published judicial opinions interpreting the scope of a statute and that both judges and litigants rely on those published opinions in future litigation.

Settlement and rule-making opportunities are not mutually exclusive. Rule-making opportunities occur at different points in the life of a litigated case. Some written judicial opinions set forth interpretations of a remedial statute without resolving all the issues in the case. For example, when deciding summary judgment motions, courts sometimes interpret the legal requirements of a claim without resolving the underlying dispute. Even if the case settles as a result of this ruling, settlement does not remove the judicial interpretation of the law from the public record. ${ }^{8}$

Significantly, choosing to litigate also does not ensure that a rule-making opportunity will occur. Jury verdicts usually do not produce judicial opinions and therefore do not become part of the persuasive or binding judicial authority interpreting the requirements of a statute. Thus, not only settlement behavior but also the litigation process and the rule-making opportunities it presents must be examined to understand how law evolves.

In an employment suit, litigation proceeds in a series of steps, many of which present rule-making opportunities. An employment lawsuit in federal court typically begins with a complaint. ${ }^{9}$ Motions to dismiss for failure to state a claim upon which relief may be granted are often the next step in litigation, followed by an answer. ${ }^{10}$ After these initial steps, the parties typically engage

8 The exception is vacatur or stipulated reversal. Vacatur involves a situation in which the parties settle a case after a court has entered judgment and issued a written opinion, and the settlement is conditioned on the court vacating its judgment. The Supreme Court recently limited this practice (U.S. Bancorp Mortgage Co. v. Bonner Mall Partnership 1994). California courts allow the practice of stipulated reversal by which the appellate court reverses the lower court's judgment to accommodate a settlement.

9 Sorne cases enter federal court through the process of removal. See 28 U.S.C. 1441 et seq.

10 Motions to dismiss also may be brought on other grounds, such as jurisdiction, which are less likely to result in a substantive interpretation of the statute underlying a plaintiff's claims. 


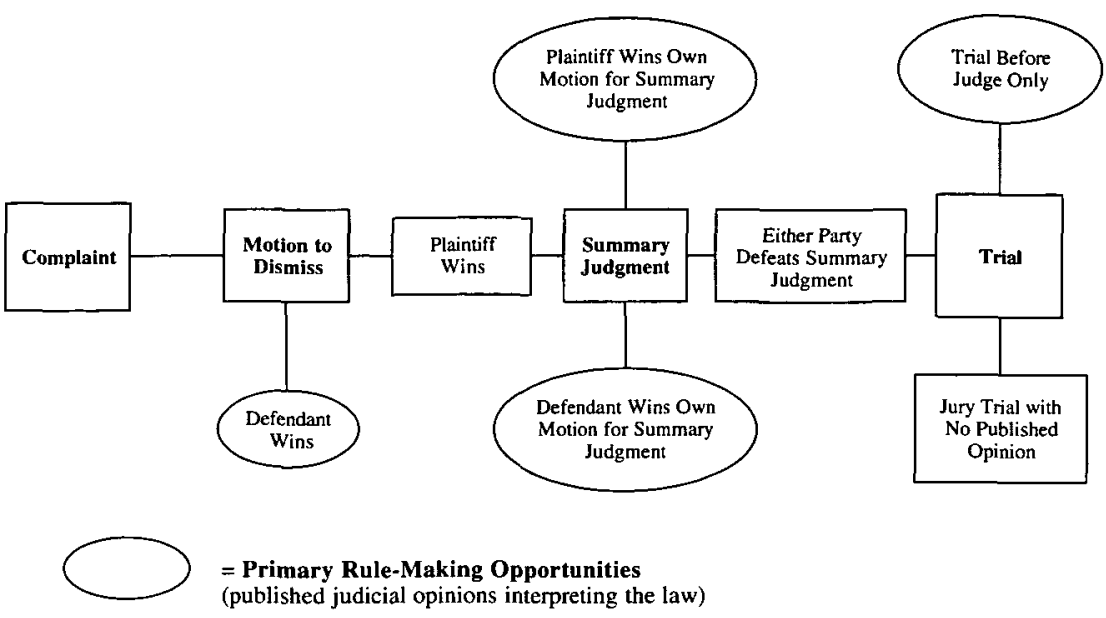

Fig. 1. Rule-making opportunities in the litigation process

in a relatively long period of discovery regarding the underlying facts of the case. Toward the end of discovery, one or both parties may bring a motion for summary judgment to narrow the issues for trial or dispose of the case entirely. Should the claim survive summary judgment, the case may proceed to trial, typically a jury trial in employment disputes. During or after trial, the parties may bring a variety of trial-related motions. Once the parties receive a final judgment, the case may, but does not always, proceed to appeal. Figure 1 illustrates this process.

Only certain points in the litigation process present opportunities for a substantive interpretation of the statute underlying the employee's cause of action. The most common rule-making opportunities in employment disputes are motions to dismiss for failure to state a claim and motions for summary judgment. These motions may produce written judicial opinions that interpret a statute's substantive legal requirements in a particular factual context. Although courts commonly address a variety of discovery disputes, these disputes rarely involve substantive interpretations of the underlying statute.

Courts sometimes designate their written opinions for publication in official reporters and through electronic databases; other opinions are filed only in the case file at the courthouse. Opinions published in official reporters generally may be cited to any other federal court, and both parties and courts have access to these opinions through a variety of indexing systems. Online electronic databases such as Westlaw or LEXIS contain all opinions that appear in the official reporters and collect some additional cases not designated for publication in official reporters. These additional cases may come from judges or parties or sometimes are sought out by the database service itself (Olson 1992). Although courts and litigants can access opinions that are published electronically but not in the official reporters, some courts 
do not allow litigants to cite officially "unpublished" opinions in their legal papers. There is no comprehensive and systematic way for litigants and courts to access opinions that are not published in some manner.

Some points in the litigation process generally do not produce written judicial opinions. For example, the parties may settle at any point in the litigation process, but settlement generally does not produce a judicial opinion interpreting the law and thus is not a rule-making opportunity. ${ }^{11}$ Generally, jury trials also are not rule-making opportunities because they do not produce published judicial applications of law. Decisions on some trialrelated motions, such as motions for a directed verdict, are the exception.

Appellate decisions are perhaps the most important rulemaking opportunities. Published appellate opinions bind trial courts within their jurisdiction, and trial courts in other federal jurisdictions tend to find them authoritative and persuasive. Although appellate courts often issue written opinions, they do not publish every written opinion, and many restrict citation of unpublished opinions in matters before the court. ${ }^{12}$

Because different rule-making opportunities arise at different times in the litigation process, each rule-making opportunity emerges in a distinct procedural posture with a corresponding legal standard. Some rule-making opportunities may be invoked by either party, others by only one. In addition, the frequency of each type of rule-making opportunity varies; appeals are rare compared with more plentiful summary judgment motions. A single case may provide several rule-making opportunities. Not only the outcome of prior similar cases but also the distribution of outcomes and procedural postures among published opinions influence the parties' decisions to settle or go forward, as well as the outcome of future rule-making opportunities. In this way, rule-making opportunities shape the judicial interpretation of a new statutory right.

Below, I discuss the types of rule-making opportunities and their likely influence on the body of published judicial interpretations of remedial statutes such as the FMLA. To simplify the discussion, I assume that the employer will be the defendant and the employee the plaintiff in employment litigation, while recognizing possible exceptions to that assumption.

11 The rare exception is a consent decree or judicially approved settlement in a class action.

12 At least one commentator has noted the problems associated with this practice (Slavitt 1995). 
The legal standard for motions to dismiss for failure to state a claim on which relief may be granted favors plaintiffs. These motions test the legal sufficiency of the claim; the court evaluates whether the facts alleged, if true, would entitle the plaintiff to a legal remedy. ${ }^{13}$ Courts construe the complaint in the light most favorable to the plaintiff, accept the factual allegations in the complaint as true, and grant the motion only if the plaintiff could prove no set of facts that would support a claim for relief. ${ }^{14}$ Courts generally do not consider factual materials outside the pleadings on motions to dismiss for failure to state a claim; if either party includes factual materials, the court may convert the motion to one for summary judgment. ${ }^{15}$

This plaintiff-friendly standard suggests that employees should win most motions to dismiss in employment cases. Defendant employers, however, are unlikely to bring these motions in every case. Bringing an unsuccessful motion to dismiss may simply waste resources and antagonize the court if the court concludes that the employer brought the motion for purposes of harassment or delay. In addition, an employee who survives a motion to dismiss may increase his or her settlement demand. Finally, motions to dismiss on correctable defects seldom result in final judgments, as courts liberally permit amendment of the pleadings. ${ }^{16}$ Consequently, a motion to dismiss on a correctable error may simply alert the plaintiff to the need to develop further evidence without disposing of the case. Because motions to dismiss arise early in a dispute, employers may simply wait to dispose of the employee's claim on summary judgment. Thus, rather than routinely filing a motion to dismiss, employers may bring these motions more often in weak cases suffering from legal defects that cannot be cured.

Judges' decisions about publishing opinions also may affect how the law develops. Judges may be more inclined to publish their opinions when they grant motions to dismiss than when they deny them because they believe that granting a motion to dismiss carries more precedential value than a routine denial. This inclination is not because judges are somehow biased against plaintiffs but because granting the motion disposes of the plaintiff's claims, whereas denying the motion does not change the course of the litigation.

Although many federal court opinions are widely available on electronic databases or in official reporters, not every judicial opinion appears in these sources (Songer et al. 1989; Siegelman

13 Conley v. Gibson (1957:45-46).

14 Cahill v. Liberty Mutual Insurance Company (1996:337-38).

15 Fed. R. Civ. P. 12(b).

16 Fed. R. Civ. P. 15; Foman v. Davis (1962:182). 
\& Donohue 1990; Olson 1992). Indeed, the Judicial Conference of the United States has suggested that federal appellate and district court judges should only authorize publication of opinions that are of general precedential value (Olson 1992). If judges, publishers, or litigants tend to select for publication those cases in which judges grant motions to dismiss, the law available to litigants and courts will contain more authority for granting employers' motions at this procedural point in the litigation process.

Given these factors, one would predict (1) that rulings on motions to dismiss would be some of the first published opinions regarding a new law, (2) a tendency for defendants to prevail in those published opinions, and (3) fewer motions to dismiss than motions for summary judgment in the published body of case law interpreting a new statute.

\section{Summary Judgment}

Summary judgment allows courts to resolve cases without the expense of trial where the undisputed facts show that one party is entitled to judgment. Summary judgment permits piecemeal resolution of the case, such as establishing liability without determining damages, but may also dispose of the case entirely and thus become an appealable final judgment. Parties often bring summary judgment motions in federal employment cases to narrow the issues for trial or avoid trial altogether. Even unsuccessful motions may point out the weaknesses in the opposing party's case and prompt that party to settle rather than risk trial. Summary judgment motions can inform the judge about the facts and issues in the case, and establishing liability through summary judgment may produce settlement by narrowing the dispute to damages. Summary judgment motions typically occur later in the litigation process than motions to dismiss, but before trial.

Unlike motions to dismiss, either party may bring a motion for summary judgment, and the legal standard is weighted against the party who brings the motion. It is much more difficult for a plaintiff than a defendant to obtain summary judgment, however, because the plaintiff generally bears the burden of proof. To prevail on this motion, a defendant must show undisputed facts in its favor on only one essential element of the plaintiff's claim, thereby negating the plaintiff's ability to prove his or her case. In contrast, to prevail, a plaintiff must show that the facts establishing each element of the claim are undisputed, a difficult burden to carry. Moreover, because summary judgment presents a rule-making opportunity, plaintiffs with undisputed facts supporting every element of their claims are unlikely to reach this stage; as discussed earlier, such clear-cut winners settle. 
Simply defeating a defendant's summary judgment motion is a success for a plaintiff because it preserves the case for trial and often produces settlement. Nevertheless, judicial decisions regarding which opinions to publish may limit the availability of this type of precedent for future cases. Judges may be more inclined to publish opinions granting summary judgment, to either party, than opinions denying summary judgment because they believe that a decision that resolves the dispute is a more significant, and thus precedent-worthy, decision. Because it is more difficult to prevail on summary judgment as a plaintiff than as a defendant, however, one would expect the universe of published opinions granting summary judgment to contain many more defendant victories than plaintiff victories.

This discussion suggests that summary judgment will be the most common rule-making opportunity in federal employment cases. In addition, because plaintiffs bear the burden of proof, one would expect to see more defendants than plaintiffs prevail on their own motion for summary judgment. Consequently, it is likely that the early weight of authority addressing a new law will involve summary judgment motions, and most published judicial opinions will be resolution of motions for summary judgment in which the defendant prevails.

\section{Jury Trial and Trial-Related Motions}

Jury trials are rare. The Federal Judicial Center estimates that only about $7 \%$ of cases brought under federal employment statutes reach trial (Judicial Conference of the United States 1995:Table C4). Some of these cases will settle during trial, leaving an even smaller number of cases on which courts may issue trial-related opinions. Although trial-related opinions such as directed verdicts are possible, those cases resolved by jury verdicts generally do not require a judicial opinion. Some bench trials may result in a published judicial opinion, although in employment cases most plaintiffs prefer a jury trial. Therefore, an employment case resolved by trial may affect the development of law no more than a case that settles.

Even without a published judicial opinion, jury verdicts still may be disseminated, however. Some practitioner publications provide information about jury verdicts. In addition, lawyers may share information through informal networks, unless prevented from doing so by confidential settlements. Also, employees who win at trial may receive media attention. Even when publicized, however, a jury verdict does not change the judicial interpretation of the law or hold precedential value for the cases that follow. Without a published judicial opinion, the results of trials are invisible to the developing body of precedent. 
Trials may present rule-making opportunities through trialrelated motions, such as motions for directed verdict. Because jury trials themselves are relatively rare, however, opinions addressing both trial-related motions and appeals of jury verdicts will also be relatively rare among judicial interpretations of a statute. Decisions at trial will occur later in the litigation process than motions to dismiss and motions for summary judgment.

\section{Appeal}

Of all the rule-making opportunities in the litigation process, appeals are the most important because published appellate decisions bind lower courts within the appellate court's jurisdiction. Because appeals are drawn from final dispositions in the trial courts, the procedural posture of appeals will reflect the distribution of procedural postures of dispositive decisions in the trial courts. ${ }^{17}$ Appellate outcomes are affected by the procedural posture of the final judgment that is appealed because that procedural posture determines the legal standard on appeal. Appellate courts review motions for summary judgment de novo, revisiting the question from the same position as the district court. ${ }^{18}$ The standard of review for a jury verdict in a civil case, however, requires an appellant to show that the verdict is not supported by substantial evidence, a difficult standard to meet. ${ }^{19}$

Appeals are not automatic. They must be actively "mobilized," and only losing parties may do so. The decision to appeal provides another opportunity for strategic behavior to influence the development of law. Repeat players may choose to appeal only those cases in which they believe they are likely to succeed and forgo less promising appeals that may reinforce unfavorable decisions. Repeat players may also settle a one-shot player's appeal if the appeal appears likely to succeed. In some instances, repeat players may condition settlement of their own appeal on vacating the unfavorable lower court ruling, removing its effect on future litigation (Slavitt 1995; Purcell 1997). Although in employment cases the repeat player is likely to be the employer, public interest organizations engage in this strategic behavior as

17 Although interlocutory appeals of nonfinal decisions are possible, an appellant must meet a high standard to obtain an interlocutory appeal. To certify an interlocutory appeal, a district court must find that the nonfinal order (1) involves a controlling question of law (2) as to which there is substantial ground for difference of opinion and (3) that an immediate appeal from the order may materially advance the ultimate termination of the litigation (28 U.S.C. 1292(b)). Interlocutory appeals are not routinely granted, and are available only in exceptional circumstances (Coopers $\mathcal{E}$ Lybrand $v$. Livesay [1978:474]). None of the appeals in this study was an interlocutory appeal, but one case involved an appeal under a related doctrine, the collateral order rule. See Eastus $v$. Blue Bell Creameries, L.P. (1996).

Warren v. City of Carlsbad (1995:441).

19 Murphy v. FDIC (1994:1495). 
well, litigating test cases likely to create precedents favorable to their interests.

For the reasons explained above, the largest category of appealable trial court decisions is likely to be orders granting summary judgment. In addition, because summary judgment occurs relatively early in the litigation process, the earliest appeals under a new statute are likely to be appeals of orders granting summary judgment. Appeals take time, and the appeal process alone will delay the appearance of appellate opinions interpreting the new law. Thus, one might predict that appellate opinions will not appear until some time after enactment of a new law and that district court opinions form the primary legal authority in the initial years of a new remedial statute.

\section{The Winnowing Process}

One way to think about the winnowing process from initial dispute to lawmaking opportunity is to conceptualize a distribution of possible cases, ranging from "weak" to "strong" and consider how prelitigation processes may screen out particular cases. Determining the quality of a given legal case is necessarily an inexact and subjective process. Most models of the litigation process, however, assume that both lawyer and litigants engage in a rational decisionmaking process to decide whether to proceed with litigation (see, for example, Priest \& Klein 1984).

One might expect that the cases at either end of the distribution would be weeded out fairly early in the process. For example, plaintiffs' lawyers typically screen potential cases before agreeing to represent new clients. Consequently, potential plaintiffs with very weak cases may find it difficult to obtain legal representation and be unwilling or unable to pursue their claims pro se. Cases can be "weak" for a variety of reasons, such as suffering from a fatal defect such as the statute of limitations or because the evidence of wrongdoing is not strong. In addition, a few cases are dropped or dismissed for lack of prosecution even after they reach federal court, suggesting that plaintiffs may abandon weak claims after filing (Siegelman \& Donohue 1990:1155).20

20 Some plaintiff's attorneys also may be reluctant to bring weak cases that are likely to produce precedent unfavorable to employees. Galanter's analysis suggests, however, that this situation is most likely where plaintiff's counsel has the characteristics of a repeat player, such as a public interest organization or government agency. These organizations may choose their test cases carefully to present the strongest possible facts to argue for a strengthening or extension of the law. Individual practitioners with significant financial pressures may be more likely to evaluate cases on a case-by-case basis for their potential for a successful (and speedy) settlement, without an eye toward the development of the law. Other factors affect screening as well. Cases that are likely to be resolved one way or the other early on with minimal effort may be the most attractive to lawyers. Cases that require a significant investment of resources in depositions and expert witnesses, even those with a high likelihood of success, may be less attractive to lawyers, particularly because many employment cases involve contingency fees. 
A similar process screens particularly "strong" cases. Potential plaintiffs with strong cases may be able to negotiate settlement with their employers, even without the assistance of legal counsel. Many attorneys routinely send demand letters to potential defendants before filing an action, and strong cases may settle at this stage. In employment actions, plaintiffs often must pursue administrative remedies as a prerequisite to filing suit, and many disputes may be resolved through this process. As discussed above, plaintiffs with strong cases that proceed to litigation may also, with the aid of preliminary discovery, establish undisputed facts early in the process showing they are likely to prevail. At this point, defendants are likely to settle to avoid additional costs of litigation or future damaging revelations in discovery.

The remaining cases are not as clear. Cases that fall in this middle range may involve disputed questions of fact, or uncertain interpretations of law, such that the outcome is difficult to predict. In those cases closer to the strong end of the spectrum, the facts and the law may slightly favor the plaintiff. In these cases, as discussed above, defendants may be less likely to file a motion to dismiss. Also, Galanter's analysis would predict that defendants would settle these cases to avoid creating a negative ruling at a lawmaking point such as summary judgment, because defendants have a long-term interest in preventing precedent unfavorable to them.

Some cases in the middle of the spectrum will be equally uncertain for plaintiff and defendant. Where that uncertainty results from disputed facts, the case is likely to go to trial or to settle shortly before trial. Disputed facts will preclude summary judgment, regardless of which party brings that motion, and the court is unlikely to publish an opinion on this nondispositive ruling. Where uncertainty results from unsettled law, Galanter's analysis suggests that defendants may settle before reaching a lawmaking point in the process to avoid creating precedent unfavorable to them.

Cases closer to the weak end of the spectrum may be those in which the facts and law slightly favor the defendants. Galanter's theory suggests that defendants will proceed in these cases because these are the cases defendants think they are likely to win. Defendants may win cases suffering from legal defects on a motion to dismiss. In addition, defendants may bring a summary judgment motion before attempting to settle because success on summary judgment is likely and the judge is unlikely to publish an opinion in an unsuccessful motion. Consequently, one might predict that many of the lawmaking opportunities would occur at summary judgment, on relatively weak cases. 


\section{The Family and Medical Leave Act}

Data

The Family and Medical Leave Act of 1993 is one of the most recent remedial statutes enacted by Congress. It provides up to 12 weeks of unpaid leave per year for certain employees to care for a seriously ill family member, the employee's own serious illness, or the birth and/or care of a new child. ${ }^{21}$ The law requires employers to hold an employee's job, or one like it, open for the employee during his or her leave and to continue to pay the employee's health care premiums during the leave to the same extent the premiums were paid before the leave. ${ }^{22}$ An employee's use of leave may not be the basis for any negative employment action, such as demotion, discipline, or termination. ${ }^{23}$ Although the FMLA essentially creates an employment benefit, it is structured as an individual right, enforceable through a private right of action or through an action by the secretary of labor. ${ }^{24} \mathrm{Ag}$ grieved employees may file a complaint with the Department of Labor, or they may proceed directly to court. ${ }^{25}$

The FMLA changes the relationship between employers and employees by carving out a protected area from the norm of atwill employment. It also challenges the traditional line between the public life of employment and the private life of the family. Prior to its enactment, employers had broad discretion to grant or deny leave and to terminate employees who needed time off from work for family responsibilities. Moreover, although many employers voluntarily provided leave to some of their employees before the FMLA, blue-collar, production, and service workers were the least likely to enjoy these benefits. ${ }^{26}$ Thus, the FMLA protects individuals who need and use leave against negative employment actions and provides significant new protections to less advantaged workers.

The FMLA provides an opportunity to examine the operation of a remedial statute in the context of litigation involving a repeat player versus a one-shot player. In addition, because the FMLA provides a federal cause of action, FMLA suits can be evaluated nationally through both trial-level and appellate opinions. Unlike state trial court opinions, many federal trial court opinions are published in official reporters or are accessible through electronic databases. The availability of trial court opinions allows closer examination of how the litigation process at the trial

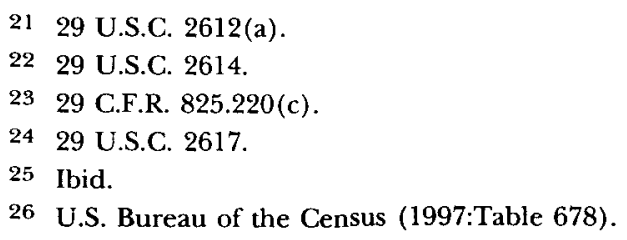


level produces law through published opinions, as well as how the distribution of trial-level outcomes and procedural postures influences the nature of appeals. ${ }^{27}$ Moreover, the FMLA provides an opportunity to examine who wins in published judicial opinions interpreting an individually mobilized statutory right. Do remedial statutes give the rule advantage to plaintiffs seeking to enforce that right? Does the litigation process affect the outcomes reflected in published judicial opinions in the early life of this new law?

The data presented are drawn from published judicial opinions interpreting the FMLA in the first 5 years after the statute was enacted. An electronic database search for FMLA cases decided by federal courts from 1993 through 1997 produced an initial list of 288 trial-level opinions and 58 appellate opinions. ${ }^{28}$ Of these, 64 trial-level opinions and 25 appellate-level opinions involved cases where the plaintiff did not bring a FMLA cause of action; these opinions were excluded from the data set. ${ }^{29}$ The remaining 221 trial-level opinions and 36 appellate opinions were coded on a number of factors, including their procedural posture, the gender of the plaintiff, whether the opinion was published in official reporters, the prevailing party, the date of the opinion, amicus curiae participation in the matter, and public interest or government representation of the plaintiff.

It is important to note that the unit of analysis for these data is the published opinion and not the lawsuit itself. One lawsuit could and in a few instances did result in more than one written opinion. Because this article addresses the evolution of judicial interpretations of a remedial statute, however, it is appropriate to include all the published opinions interpreting that statute even where the underlying lawsuit may be included more than once.

Because this study examines published judicial opinions, some cautions are in order here regarding using published opinions in law and society research. It is well known that not all judicial determinations are published, either in electronic databases such as Westlaw and LEXIS or in the official reports such as the Federal Supplement (Songer et al. 1989; Siegelman \& Donohue 1990; Olson 1992). For example, Songer et al. found that almost $40 \%$ of all cases filed in the Eleventh Circuit in 1986 went unpublished (Songer et al. 1989:969). Siegelman and Donohue found

27 Although both state and federal courts have jurisdiction over FMLA claims, even FMLA claims originally brought in state court will likely end up in federal court through the process of removal.

28 These opinions include opinions published only in an electronic database and opinions published in the Federal Reporter or Federal Supplement. The FMLA was enacted in 1993 , and no published opinions were found for that year.

29 Often, judges mentioned the FMLA in passing in circumstances where the plaintiff had taken a leave from the employer but did not include a FMLA cause of action in his or her complaint. Some irrelevant cases came up because the acronym FMLA also refers to the Federal Maritime Lien Act. 
that roughly $80 \%$ of the 4,310 employment discrimination cases they studied did not produce a published opinion (1990:1137). Siegelman and Donohue note that the small proportion of cases that produce published opinions renders the representativeness of published opinions suspect, because "other things equal, published cases are more likely to be representative of unpublished cases if the ratio of published to unpublished is 1:2 than if it is 1:10" (ibid., p. 1139).

The research suggests that other, nonrandom factors may also affect the selection of cases that generate published judicial opinions. Songer et al. (1989) classified the litigants in their cases as "upperdogs" (government and corporations) and "underdogs" (labor unions, individuals, minorities, aliens, and convicted criminals). The publication rate for cases in which "upperdogs" were the appellants was higher than for those cases in which the "underdogs" were the appellants, and this difference was statistically significant. Songer et al. also noted that in civil rights cases in particular, only $49 \%$ of cases in which the "underdog" was the appellant were published, compared with the $80 \%$ publication rate for cases in which the "upperdog" was the appellant. To the extent that "upperdogs" are also repeat players under Galanter's framework, this finding lends some support to the idea that repeat players have greater influence over the development of legal precedent than one-shot players.

Factors unrelated to the nature and identity of the parties may also affect the representativeness of published opinions. For example, Siegelman and Donohue concluded that publication rates varied geographically for employment discrimination cases, indicating that relying solely on cases with published opinions will generally produce a geographically skewed sample of all cases filed in the United States (Siegelman \& Donohue 1990:1144).

In addition, as Siegelman and Donohue (ibid., p. 1146) note, it is likely that rulings that dispose of . case are more likely to be written and more likely to be publisł.ed that those that do not. This observation suggests, for example, that even if a plaintiff's case is strong enough to survive summary judgment, an opinion denying summary judgment to the defendant is unlikely to be published. Siegelman and Donohue also point out that judges are more likely to publish opinions with dispositive rulings, and therefore settlement will tend to reduce the likelihood that any given case will generate a published legal opinion. Indeed, they found that settlement in cases without published opinions, $68 \%$, was much more frequent than settlement in cases with published opinions, 35\% (ibid., p. 1155).

In the discussion below, I suggest how strategic settlement and the litigation process combine to affect the representativeness of published opinions. 


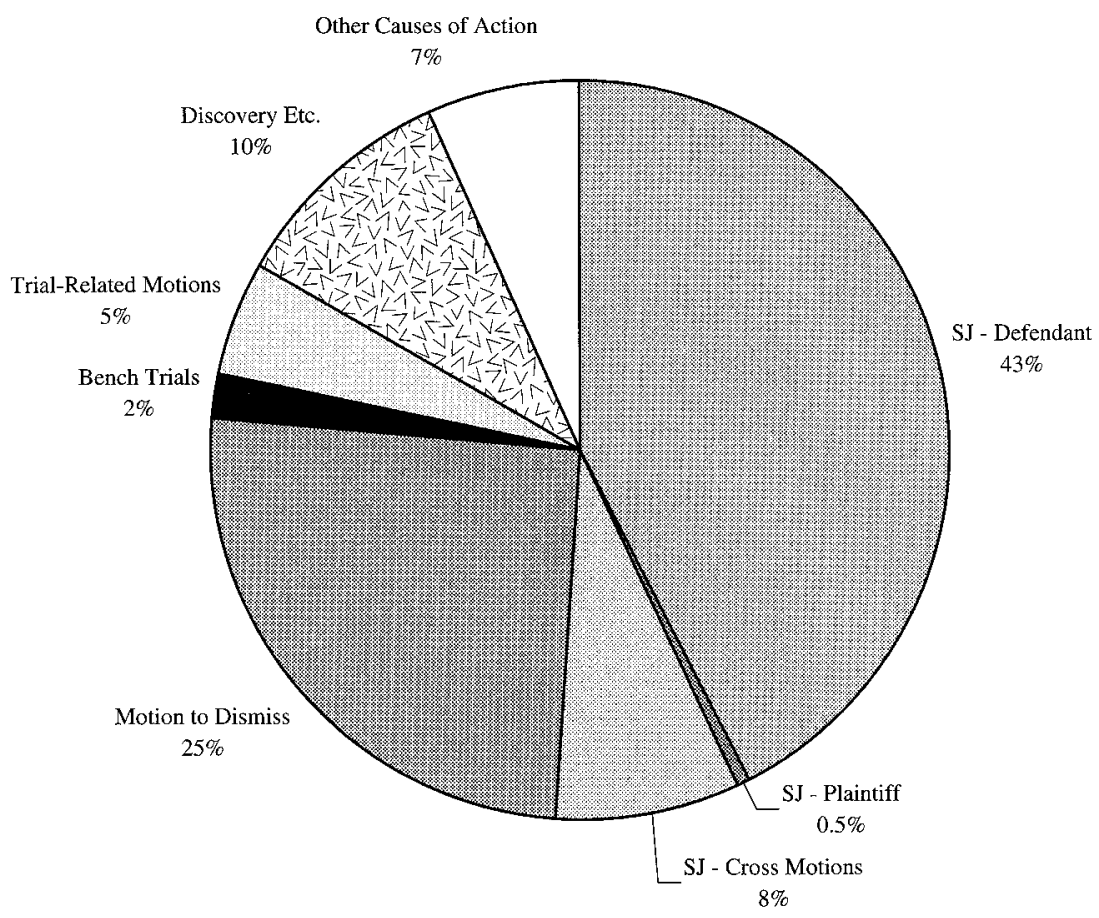

$\mathrm{N}=221$

Fig. 2. Distribution of procedural posture, district court FMLA opinions

\section{Results and Discussion}

\section{Distribution of Procedural Posture in Early Opinions}

Figure 2 shows the procedural posture of FMLA cases at the district court level that were published in the first 5 years after the statute was enacted. As expected, the most frequent procedural posture was summary judgment, which constituted about half the published opinions. Motions to dismiss were the next most common published opinions. Approximately $21 \%$ of the published opinions were motions to dismiss for failure to state a claim under Federal Rule of Civil Procedure 12(b) (6). Another $4.5 \%$ were motions to dismiss for other reasons, such as lack of jurisdiction. There were only four bench trials recorded in these published opinions. In addition, 11 opinions were trial related, such as motions to exclude evidence or motions regarding fees. Finally, 22 of these opinions were nondispositive discovery disputes or other types of motions, including motions regarding other legal claims in the lawsuit and motions to compel arbitration.

Figure 2 shows that the weight of authority interpreting the FMLA involved motions for summary judgment and motions to 


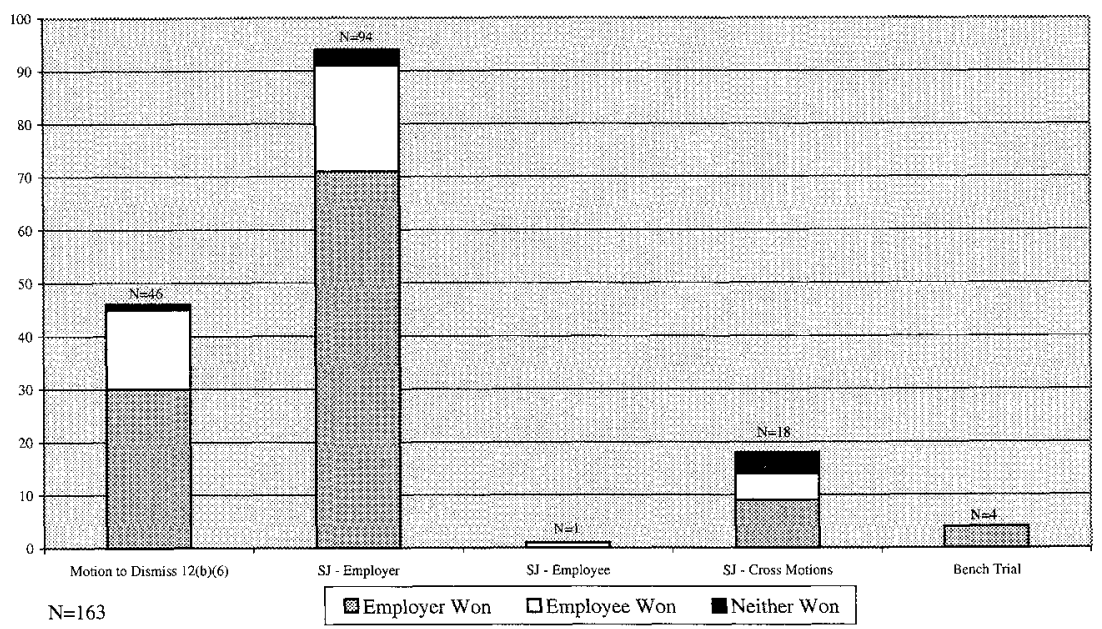

Fig. 3. Outcomes by procedural posture, district court FMLA opinions

dismiss, both of which increased in number over time. The vast majority of early published judicial interpretations of the FMLA were based on these two rule-making opportunities in the litigation process.

\section{Distribution of Outcomes by Procedural Posture in Early Cases}

Figure 3 shows the distribution of outcomes for trial-level published opinions in the primary rule-making opportunities in the litigation process: motions to dismiss for failure to state a claim, motions for summary judgment, and bench trials. The practical meaning of an outcome clearly depends on the procedural posture of the opinion; an employee who survives the employer's summary judgment motion does not win the case, but preserves the claim and may present it to the trier of fact. An employee who prevails on his or her own motion, however, wins at least some of the case outright. Outcomes coded "other" are situations in which neither party prevailed (such as a denial of both motions on cross motions for summary judgment) or in which the outcome was too mixed to declare one party the victor. Although plaintiffs may have sued under several different but related employment statutes, "wins" and "losses" were coded with regard to only the employee's FMLA cause of action.

As predicted, in the published opinions, employers prevailed much more often than employees when the employer was the only moving party on summary judgment; employers won $76 \%$ of their own motions for summary judgment. Where both parties brought motions for summary judgment, however, employers prevailed only $50 \%$ of the time. Outcomes on cross motions may be more balanced because those cases in which employees also brought summary judgment motions were stronger claims. Em- 
ployees did better in these cases, $28 \%$ winning on their own motion, and $22 \%$ defeating the employer's motion. Nevertheless, there were many more published opinions in which only the employer moved for summary judgment $(N=94)$ than in which the court addressed cross motions for summary judgment $(N=18)$. By far the largest category of published opinions were grants of the employer's motions for summary judgment $(N=80)$.

Published opinions on employers' motions to dismiss for failure to state a claim show a similar pattern. Employers prevailed two to one over employees in these opinions. Once again, "prevailing" was coded only on the FMLA cause of action. Despite the dominance of employer success, given the theory that employers would only bring motions to dismiss where they were likely to win, it is somewhat surprising that so many employees defeated motions to dismiss. Closer examination revealed that in many cases, the employer's motion to dismiss encompassed not only the employee's FMLA claim but also other causes of action in the lawsuit. Therefore, employers may have evaluated the chances of success of the motions to dismiss with reference to other causes of action and simply added the FMLA claim because they were bringing the motion anyway.

Employees lost the few bench trials reported, which may simply be a fluke in the small number of bench trials reported $(N=$ 4). It may also reflect unequal skill levels in representation of the parties. Generally, plaintiffs' attorneys request a jury trial, believing that a jury will be more sympathetic than a judge and hoping for a large compensatory damage award.

For all opinions, the likelihood of prevailing did not differ significantly by gender of the plaintiff. Also, there was no significant difference in outcome between opinions published in the electronic database and those published in the Federal Reporter or Federal Supplement.

\section{Appeals}

As predicted, appeals were relatively rare and took time to work their way through the courts. Only 36 of these 257 published opinions were appeals. See Table 1. Of the 36 reported appellate cases, 30 were decided in 1997, 5 in 1996, and only 1 in 1995. In addition, appeals reflect the influence of the litigation process at the trial level. Sixty-seven percent of published appellate opinions were appeals of a decision granting summary judgment to the employer, reflecting the large number of these types of final judgments. The remaining opinions were scattered among various other types of final judgments, including judgments on claims other than the employee's FMLA cause of action. Only one appeal involved the grant of a motion to dismiss, 
Table 1. Procedural Posture on Appeal in FMLA Actions $(N=36)$

\begin{tabular}{|c|c|c|c|}
\hline Procedural Posture of Decision Appealed & Number & $\begin{array}{c}\text { Employer } \\
\text { Won }\end{array}$ & $\begin{array}{c}\text { Employee } \\
\text { Won }\end{array}$ \\
\hline Grant of summary judgment to employer & 24 & 19 & 5 \\
\hline Grant of motion to dismiss & 1 & 1 & - \\
\hline Judgment for employer following bench trial & 2 & 2 & - \\
\hline Trial-Related Motion & 2 & 2 & - \\
\hline Non-FMLA cause of action & 2 & 2 & - \\
\hline Other & 5 & 5 & - \\
\hline Total & 36 & 31 & 5 \\
\hline
\end{tabular}

which is not surprising because a plaintiff generally may amend a complaint after losing a motion to dismiss.

In general, appellate courts tend to uphold trial-level decisions. Data from the Administrative Office of the United States Courts indicate that more than $80 \%$ of appeals terminated on the merits in the 12-month period ending September 30, 1995, were affirmed or enforced (Judicial Conference of the United States 1995:Table B5). Published employment opinions in this study followed the pattern reported by the Administrative Office of the United States Courts. Employees were the appellants in every published appellate opinion except two, and employees seldom succeeded on appeal. Employers prevailed in approximately $86 \%$ of published appellate opinions.

These data show some trends in the published judicial determination of rights early in the life of this employment statute. First, employers' motions for summary judgment and motions to dismiss were by far the largest categories of published opinions, supporting the hypothesis that motions to dismiss and motions for summary judgment are the most common rule-making opportunities in the litigation process. Appeals reflected the distribution of procedural posture at the trial level and rarely overturned the outcome at the trial level.

Second, in these dominant groups of published opinions, the "haves" come out ahead. Employers prevailed two to one against employees on motions to dismiss, nearly three to one against employees on motions for summary judgment, and four to one on appeal. Consequently, judges reviewing the state of the law and practitioners deciding whether to take on a case will find that the published case law suggests that employees seldom prevail.

These data are consistent with Galanter's argument that repeat players play for the rules; that is, repeat player employers settle cases they are likely to lose, and litigate cases they are likely to win. Indeed, the incentive to engage in this behavior may be greater at the beginning of the life of a statute where almost every dispute raises a question of first impression. These data also reflect, however, the influence of the procedural posture of the rule-making opportunities in the litigation process. The most 
common rule-making opportunities involved motions for which dispositive outcomes occur primarily when employers win.

In addition, perhaps the most important insight is what is not represented in published judicial interpretations of the law: settlement and jury verdicts. That employers win in most published opinions does not necessarily mean that they prevail in most cases despite the protections of the remedial statute. The outcomes in these data may simply reflect the combined influence of strategic settlement and the characteristics of rule-making opportunities in the litigation process. Employers may settle strong cases likely to produce adverse decisions, ensuring that these cases never become the basis for a published judicial opinion. Employers may dispose of weak cases, on the other hand, through motions to dismiss or motions for summary judgment, which often do become part of the judicial interpretation of the law. Cases somewhere in between are likely to involve disputed material facts and consequently proceed to trial. Judges are unlikely to publish denials of motions to dismiss or motions for summary judgment that occur in these cases along the way, however, because these are not dispositive decisions. Many cases that proceed this far settle on the eve of trial. To the extent the rest are decided by jury, they usually do not produce a published judicial opinion that becomes part of the law.

These data only address lawsuits raising FMLA claims, and other types of litigation may produce other patterns. ${ }^{30}$ These data are consistent, however, with a recent study regarding another recent remedial statute, the Americans with Disabilities Act (ADA) (ABA Commission on Mental and Physical Disability Law 1998). In a study examining outcomes in trial and appellate cases brought under the ADA, the Commission on Mental and Physical Disability Law found that employers prevailed in $92 \%$ of the 760 opinions in which it could be determined which party prevailed. Consistent with the strategic settlement argument, one employee advocate asked to comment on the study noted that "cases that are clearly in our favor usually settle before they are decided" (Flaherty \& Heller 1998). Those cases that would have reflected employee wins may have simply never reached a rule-making op-

30 For example, one study of Title VII cases found that employees were successful to some degree in more than half the reported cases (Burstein \& Monaghan 1986; Burstein 1991). Both the measure and the sample in that study, however, are different from my approach here. That study examined only appellate cases and looked only at those cases that were published in Fair Employment Practice Cases, a publication compiled by the Bureau of National Affairs. It also used a very broad definition of "winning" and did not include any information about procedural posture or trial-level outcomes.

A different study of state court records indicated that plaintiffs in personal injury suits (the most comparable to civil rights suits) obtained formal settlement or judgments in their favor more than half the time (Wanner 1975). Wanner sampled court records rather than looking at published opinions, however, and therefore his study does not speak to bias in the published interpretations of the law. In addition, "personal injury" actions in that study include actions other than employment civil rights actions. 
portunity in the litigation process. In addition, the study excluded 440 cases in which the final outcome could not be determined. At least some of these cases may have been ones in which plaintiffs survived a motion to dismiss or a motion for summary judgment and then negotiated a settlement, leaving no record of the final outcome of the case. In other words, summary judgment often leaves a clear published record of who won, whereas settlement and trial generally do not.

What do we know about cases that did not produce published opinions, including those that may settle or go to trial? In their study of employment litigation in the federal courts, Siegelman and Donohue found that only about $20 \%$ of cases produced a published opinion (1990:1137). Although predicting the outcome of settled cases had they proceeded to adjudication is impossible, indirect evidence may shed some light on the subject. For example, Siegelman and Donohue found that settlement was nearly twice as likely among cases that did not produce published opinions than among those that did (ibid., p. 1155). Although cases may settle for many reasons, the larger proportion of settlements in unpublished cases suggest that these cases may have been more likely to survive a dispositive pretrial motion than those that produced published opinions. Indeed, Siegelman and Donohue report that more cases were resolved by defendants winning 12(b) (6) motions, summary judgment motions, and trial in cases with published opinions than in those without (ibid.). These findings suggest that the common-sense notion that stronger cases settle is not off the mark.

As for trial, few cases proceed that far. Data collected by the United States Administrative Office of the Courts indicate that $77 \%$ of employment cases terminate before reaching a pretrial conference, some without any court action (Judicial Conference of the United States 1995:Table C4). These data also indicate that approximately $7 \%$ of district court cases brought under federal employment statutes reach jury trial, apparently resolved by verdict or settlement thereafter. Some data collected from different sources suggest that plaintiffs with employment claims who make it to trial may often be successful (Gross \& Syverud 1991); other data suggest that these plaintiffs may win at trial only about one-third of the time (Siegelman \& Donohue 1990).

What are the implications of these data? The combined effects of strategic settlement and rule-making opportunities in litigation suggest that over time, the published opinions interpreting an employment statute will reflect more adjudicated wins by employers. Advocates seeking authority to support their respective positions will find substantially more published opinions in which courts granted summary judgment for the employer than for the employee. As one court noted in the context of vacatur: 
In the normal and traditional operation of the American justice system, each party walks to the courthouse with a compilation of opinions in its favor under one arm and a collection of opposing views under the other. ... In many instances, particularly in litigation involving institutional litigators, understandably enamored with the majority approach, one or both parties may state that "the weight of authority" supports their view. A string of citations follows. Courts may then, for understandable reasons, accept the majority view as the view tending toward more stability and predictability in the law and toward fewer accusations of renegade activism. (Benevides $v$. Jackson Nat'l Life Ins. Co. 1993:1289)

Because the norms of the rule of law traditionally require law to be generally and consistently applied, rules articulated in case law have implications for the resolution of future disputes. Judges decide cases and generate opinions by synthesizing existing law and applying it to the case at hand. If most published opinions, as opposed to litigation outcomes, favor employers, the synthesized law will come to favor employers' interests. Commonlaw systems of law are flexible; judges may revise and distinguish rules when faced with counterfactual cases in which the outcomes suggested by the rules seem unjust. Significantly, however, the strategic settlement argument suggests that the counterfactual case will rarely, if ever, appear in the case law because it will settle before reaching a rule-making opportunity.

\section{Public Interest and Government Participation}

Galanter suggests that public interest representation or participation of amicus curiae representing the interests of one-shot players may ameliorate the advantage repeat players enjoy in shaping the law. Public interest representation was very rare in this group of cases, however. In only seven published opinions did either a public interest organization or the Department of Labor represent the employee. One case in which the Department of Labor represented the plaintiff accounted for three of these seven published opinions, a case the department eventually lost at a bench trial. The Department of Labor also brought actions on behalf of two other plaintiffs in these published opinions, losing on the employer's motion for summary judgment in one and prevailing on the merits in another. The employees represented by other public interest organizations were successful, defeating a motion to dismiss in one instance and winning the plaintiff's own motion for summary judgment in the other.

Amicus curiae participation was rare, and as expected, occurred only at the appellate level where a binding interpretation of the law was at stake. Amici participated in three appellate cases, Bauer v. Varity Dayton-Walther Corp. (1997), Manuel v. Westlake Polymers Corp. (1995), and Victorelli v. Shadyside Hosp. (1997). 
The Women's Legal Defense Fund (now the National Partnership for Women and Families) led a coalition of public interest organizations in Bauer and Manuel, and the Department of Labor also participated as amicus curiae in Manuel. The Legal Aid Society of San Francisco led a coalition of public interest organizations in Victorelli. The employee prevailed in Manuel and Victorelli, but lost in Bauer. Although the numbers are too small to draw any meaningful conclusions, on balance, public interest and amicus curiae participation appeared to improve employees' chances of prevailing. Of the eight underlying cases with either public interest representation or amicus curiae participation, plaintiffs definitively lost in only two.

The relative dearth of public interest participation in published judicial opinions may reflect public interest activities outside the judicial forum. For example, the Department of Labor accepts and resolves complaints regarding violations of the FMLA. As of June 1998, the department had received 12,633 complaints from employees and found violations of the FMLA in 7,499, or nearly $60 \%$ (Bureau of National Affairs 1998). ${ }^{31}$ The department successfully resolved $88 \%$ of complaints in which it found a violation of the FMLA, obtaining $\$ 11,772,607$ in damages from employers.

A few results are striking about the Department of Labor complaint data. First, the figures reported by the Department of Labor suggest that more disputes arise regarding the FMLA than the limited number that reach the federal courts. ${ }^{32}$ Indeed, many may not reach court because the department resolves them. ${ }^{33}$ Second, the department found violations in $60 \%$ of cases, compared with the plaintiff success rate of approximately $22 \%{ }^{34}$ in the case law, suggesting that employees may mobilize the law and win at least some remedy more often than the case law suggests. Third, the average damage award for the $88 \%$ of violations that the department resolved is approximately $\$ 1,800$, suggesting that administrative complaints address disputes over small damages, although aggregate figures include disputes that vary in value. ${ }^{35}$

31 The department found no violation in many instances because either the employer was not covered by the FMLA or the employee was not eligible for leave.

32 Of course, these figures may reflect a lag time between the violation and the appearance of the dispute in court, as the FMLA has a 2-year statute of limitation. In addition, it is unclear how many FMLA lawsuits actually reach court and then settle without any judicial action.

33 It is important to note, however, that Department of Labor administrative proceedings and participation in a federal court action are not mutually exclusive alternatives. In addition, unlike many other federal employment statutes, the FMLA does not require exhaustion of administrative remedies before filing in federal court.

34 This success rate includes success (either winning the plaintiff's own motion or defeating the defendant's motion) on all motions with published opinions, including discovery motions, even if the underlying dispute remained unresolved.

35 There are alternative explanations. The department may resolve disputes before much back pay accrues. The department may also be reluctant to be particularly punitive 
Thus, the role of the department in resolving violations may be to facilitate settlement of low-damage disputes without resort to the courts. Although this role may help overcome the advantages of repeat player employers over employees with small claims, once again these employee successes will not be reflected in the judicial determination of rights.

A twofold conclusion emerges. First, outcomes in published judicial interpretations of this employment right do indeed tend to favor the repeat player. Employers win far more often than employees in these published opinions. As Galanter would predict, this trend may result in part from the relative power of the parties, as the limited data regarding employees with public interest representation suggest that they do better. The trend, however, may also reflect the influence of the litigation process itself because the most common rule-making opportunities arise when defendant employers prevail on certain motions. The overwhelming trend in favor of employers results not only from victories in individual cases, but also from the concentration of published judicial interpretations of the law in motions to dismiss and motions for summary judgment.

This point leads to a second conclusion, which is that published judicial interpretations of the statute favor repeat player employers because published opinions may not reflect much of what a statutory right accomplishes. For example, unproblematic compliance with the remedial statute is nowhere represented in these judicial opinions because it does not create a dispute (Hadfield 1992). In addition, the common ways to succeed in an employment dispute after surviving dispositive motions-settlement and trial-do not commonly produce published opinions. Also, some cases settle before reaching any rule-making opportunity or even before reaching court. Thus, by "winning"-either by obtaining a settlement or winning a jury trial-employees render their own experiences invisible to the judicial determination of rights, which may eventually erode the power of the remedial statute.

Early Opinions and the Interpretive Path of the Law

Although the data presented here do not directly address this point, it is important to consider how this process of creating early published opinions under a new statute might shape the development of the law. The norms of the rule of law form an institutional coordination structure through which judges examine each other's positions and coordinate the development of

with employers because the law is new. Alternatively, the department may cut "sweetheart deals" with the employers, settling cases for much less than they are worth. 
law (Rubin \& Feeley 1996). ${ }^{36}$ Stare decisis and the norm of consistency may amplify the general tenor of early published opinions interpreting a remedial statute if judges seek interpretations that are consistent with the published decisions of their colleagues. Initially, the earliest published opinions may be the only interpretive guidance under a new law. Judges may then rely on these few cases to decide the next wave of disputes arising under that statute. Consequently, early published opinions addressing unsettled areas of law potentially set the direction of the interpretation of a statute. If early published interpretations favor repeat players, later judicial interpretations applying these early authorities may also favor repeat players.

Settlement and the timing of rule-making opportunities in the litigation process suggest that repeat player employers will win in the first rule-making opportunities under a new employment statute. Repeat player employers can avoid early negative rulings by settling cases they are likely to lose. In addition, most early rule-making opportunities are likely to involve motions for which dispositive outcomes occur when employers win-motions to dismiss and motions for summary judgment-because these dispositive rulings occur before trials or appeals in the litigation process. Moreover, because early appeals will be drawn from cases with adjudicated, not settled, outcomes, they are likely to involve these relatively weak cases in which courts granted employers' motions to dismiss or motions for summary judgment. ${ }^{37}$

Parties evaluate the strength of their positions by taking into account published interpretations of the law. Once a sufficient body of authority supporting an employer-friendly interpretation of the law develops, even plaintiffs with strong cases may have difficulty overcoming the weight of authority against them. Interpretations unfavorable to employees may cause lawyers to decline to take these cases and cause plaintiffs to settle their cases for less. If these circumstances arise, the scope of rights created by a remedial statute may be slowly narrowed and curtailed. ${ }^{38}$

36 There is a body of literature regarding judicial decisionmaking that disputes this proposition (see, e.g., Segal \& Spaeth 1996; Spaeth \& Segal 1999). Most studies of judicial decisionmaking that find that judges follow their preferences rather than precedent, however, examine this process at the level of the Supreme Court. There is reason to believe that trial judges will be more likely to follow precedent for fear of being reversed. Some research shows that precedent affects the decisions of appellate judges as well (Songer et al. 1994).

37 That is, appeals are likely to be appeals from grants of summary judgment to the employer in cases that the employer chose not to settle because it believed it could win. Employers are unlikely to appeal grants of summary judgment to an employee because these cases tend to be very strong. Employers are also unlikely to appeal after an employee wins a jury verdict because appellate courts are reluctant to overturn jury verdicts.

38 Negative rulings, however, can sometimes galvanize the opposition, provoke political demands for legislative reversal, and help organize social movements (McCann 1994). 
An empirical exploration of this hypothesis regarding early judicial interpretations of a statute is beyond the scope of this article, and I do not claim that the data presented here prove the validity of this argument. There are, however, intuitive reasons to believe that early interpretive paths shape the eventual scope and meaning of a new statutory right. Particularly in federal court, where courts publish many trial-level opinions, early published opinions interpreting a new law provide paths of least resistance as well as frames of interpretation for judges grappling with new statutes. Because initially there are few published interpretations of a new law, these interpretations do not compete with as many other authorities for recognition or attention. In the early life of a statute, essentially every issue raises a question of first impression. These first published interpretations offer alternatives to starting from scratch for later judges wrestling with similar problems.

Judges mindful that legitimacy of the rule of law rests in part on consistency may also be inclined to reach conclusions consistent with those of their colleagues on the bench. Although the earliest published interpretations will be trial-level opinions and therefore not binding on other courts, judges often look to their colleagues, even those in other jurisdictions, for persuasive or at least instructive resolutions of undecided questions (Walsh 1997). Once an interpretive path emerges, a judge may find it hard to reject without contrary authority to support an alternative approach, particularly in federal court where the underlying law often remains the same across jurisdictions and cannot easily be distinguished. In addition, attorneys may be reluctant to make legal arguments, particularly arguments contrary to existing authority, without some supporting authority.

Judges do not necessarily follow the path set by the first to reach a particular question, however. For example, although many judges interpreting the FMLA have borrowed the burdenshifting analysis applied in antidiscrimination cases, not all have uniformly chosen this interpretive path. A well-respected judge, Judge Easterbrook of the Seventh Circuit, broke ranks with this approach and criticized judges for adopting standards from other employment laws without considering their jurisprudential utility. ${ }^{39}$ As this example suggests, however, other judges faced with unsettled issues of law may have concluded that relying on existing authority from any source offers some assurance of reaching the right, or at least a defensible, outcome. Judges may be more likely to find a party's arguments persuasive if at least some authority supports them.

39 See Diaz v. Fort Wayne Foundry Corp. (1997). Although looking to existing interpretive paths is common, judges with greater status (or confidence) may be more likely to reject early interpretive paths they find unconvincing. 
The weight of authority among early published opinions also may affect the development of law by affecting the mobilization of a new remedial statute. That is, existing authority affects the parties' estimate of their likely success and accordingly their decisions to settle or proceed. A published opinion is a valuable resource for the party whose position it supports, both in negotiation and in arguing a position before the judge. Although cases can always be factually distinguished, it may be difficult for a party to overcome the weight of negative authority with little contrary authority to cite. Thus, if early authorities favor employers and gain increasing acceptance, employee litigants may confront a less hospitable legal landscape, notwithstanding the terms of the statute.

\section{The Rule of Law and the Paradox of Losing by Winning}

These data raise important questions about what it means to win or lose when the resolution of disputes occurs largely beyond the view of the law. They reveal a paradox in the debate among those who believe that law seldom matters for social change and those who believe that law can matter for political movements and the recognition of rights. Studies addressing who wins often treat "winning" as victory in published judicial opinions (Galanter 1975; Burstein \& Monaghan 1986; Wheeler et al. 1987; Bustein 1991). As the analysis in this article shows, however, plaintiffs and defendants do not have the same procedural opportunities to win a lawsuit through published adjudication. Many cases eventually settle, and plaintiffs may sometimes negotiate a settlement in the shadow of the law even before their disputes reach court. Indeed, plaintiffs who settle may find a favorable settlement to be as much a victory as a jury verdict after trial. Focusing on disputes alone also overlooks other ways of "winning." Many employees may "win" because their employers comply with the law or because the law subtly changes their everyday social relationships. Workers may even bargain for more than the remedial statute requires, using the legislation as leverage in negotiations (McCann 1994). All reflect tangible benefits enjoyed as a result of statutory rights.

The paradox of losing by winning, however, is that the experiences of individuals who win through settlement, trial, or other legally invisible means are not reflected in the judicial determination of rights. Even if rights mobilization creates benefits for some individuals, the coordinating power of rights adjudication is not equally available to both parties. Plaintiffs and defendants in employment rights litigation do not have the same procedural opportunities to win in the published judicial determination of rights. Courts, as passive institutions, depend on the private mobilization of rights to create both caseloads and rule-making 
opportunities (Black 1973). Consequently, when repeat player defendants settle cases they are likely to lose, judicial determinations of rights are based on a selective group of weaker cases. Courts' published opinions do not reflect disputes that eventually settle or result in jury verdicts, nor do they show the benefit of rights in everyday life. At least in employment litigation, the rule-making opportunities in the litigation process magnify this effect by concentrating published judicial determinations of rights in motions where dispositive outcomes occur primarily when employers win: motions to dismiss and summary judgment motions.

Although this point is significant, it is important not to overemphasize the formal law. Courts interpret the law, but what the law will mean flows from the interpretation and transformation of law in ordinary, everyday interactions. Formal legal rules do not predetermine compliance or social behavior. Law's relationship to social practices is not simply instrumental and unidirectional; these practices may inform the formal law as much as the other way around (Erlanger et al. 1987; Yngvesson 1988). Other normative factors may matter more than legal rules in certain social interactions (Macaulay 1963; Ellickson 1991; Erlanger et al. 1987; Maccoby \& Mnookin 1990). Organizational culture may translate and transform law's meaning in institutional settings (Edelman et al. 1993). In some instances, organizations may adopt policies to comply with civil rights statutes regardless of the courts' eventual interpretation of those statutes (Kelly \& Dobbin 1999). Law's ultimate utility may be as an organizing principle around which to build a social movement; legal defeats may serve this purpose to the same extent as legal victories (McCann 1994). Also, social forces may affect adjudication to counterbalance the process to some extent. Thus, an instrumental, top-down and unidirectional conception of law's relationship to society does not capture its nuances.

Nevertheless formal law remains relevant to social change and everyday life (Engel \& Munger 1996). Judicial decisions are important signposts about the meaning of rights; they do more than resolve the disputes of parties. Through adjudication, courts communicate the scope and moral force of remedial statutes.

The relative influence of any legal outcome, however, depends on effective communication of the result and its meaning (Galanter 1983). Not every outcome in the litigation process is communicated equally: grants of summary judgment may become precedential rulings, jury verdicts generally do not. Confidentiality agreements and the dearth of information about settlements limit the influence of settlement compared with a written judicial opinion (Erlanger et al. 1987). By limiting communica- 
tion of some outcomes, the litigation process may also limit rights' scope and effect.

By deciding disputes, courts specify what constitutes compliance with the law and induce compliance from parties and organizations that may never appear in court (Galanter 1983). For example, employers may evaluate their compliance with the FMLA according to courts' enforcement of employees' rights to leave. If FMLA claims reported in judicial opinions rarely succeed, employers may make fewer efforts to comply with the law. In addition, published opinions in which employers consistently win may create an employer-friendly standard for compliance with the law. ${ }^{40}$

Published judicial opinions also affect private ordering through negotiation. Legal rules establish each party's bargaining endowments in negotiations by indicating the likely outcome should negotiations fail (Mnookin \& Kornhauser 1979). If published judicial interpretations of the FMLA favor employers, employers will enjoy an advantage in negotiations by having more legal authority to support their position and arguments. In contrast, little information exists about average settlements or jury awards in similar cases, short of the attorney's own experiences, because these outcomes are difficult to track (Erlanger et al. 1987). ${ }^{41}$ Consequently, even employees with strong claims may be forced to lower their settlement demands because they cannot

40 For example, the Seventh Circuit recently ruled that employers with a good faith belief that an employee on leave was not actually sick, even if incorrect, could legally fire that employee for taking leave (Kariotis v. Navistar Int'l Transp. Corp. 1997). In this case, the employer hired a private investigator to follow an employee who recently had knee surgery. The investigator recorded her on videotape pushing a grocery cart in the supermarket. When fired, the employee offered additional medical certification of her inability to work, which the employer refused. In addition, the employer refused to arrange an examination by its own doctor, a procedure that the FMLA regulations set forth for these circumstances. The Seventh Circuit ruled that the employer was not obligated to follow those compliance procedures as long as it had a good faith belief that the employee was lying.

41 Lawyers have professional networks and exchange information regarding similar cases so that informal sources of information may help overcome the information deficit faced by plaintiffs. In addition, publications other than the official reporters, such as professional newsletters or jury verdict reports, also provide information about the more "invisible" outcomes. Because these sources generally cannot be cited to the court as authority, however, they may be most useful in negotiating settlements. Moreover, in the context of employment litigation, particularly litigation involving a new remedial statute, there is reason to believe that these factors may not reduce the disadvantage of plaintiffs much. Employment cases are notoriously fact-intensive and often turn on minor differences in the evidence, rendering experiences of other attorneys in all but the most similar cases somewhat irrelevant. In addition, the confidentiality clauses often inserted in settlement agreements may restrict precisely this kind of informal exchange. Finally, because the FMLA is a relatively new law, few attorneys have much experience litigating FMLA cases, which limits the amount of informal exchange that can take place. My own experience as a practicing attorney also suggests that publication of a favorable opinion in the official reporters is an important factor in facilitating this informal exchange, as attorneys often call the attorney of record in published opinions to request sample pleadings and technical assistance. To the extent that favorable outcomes do not produce published opinions, the informal exchange of information may be dampened. 
point to any objective authority showing the success of a similar claimant.

The influence of the litigation process on published authority may also affect the future mobilization of rights. Published opinions showing successful claims may encourage wronged individuals to "name" their injury and claim a remedy or may energize a social movement (Black 1973; Felstiner et al. 1984; McCann 1994). Conversely, published opinions documenting unsuccessful claims may cause potential plaintiffs to conclude that success is unlikely and therefore forgo their claims. Published judicial opinions in losing cases may curtail plaintiffs' access to legal representation because attorneys, particularly those who take cases on contingency, decide that those claims are too financially risky to undertake. Thus, the invisibility of successful claims may diminish the mobilization of employment civil rights.

A steady parade of rulings against employees may also undermine the moral authority of the underlying right itself because laws have constitutive as well as instrumental influence in society (Sarat \& Kearns 1993). Judicial interpretations enter a dynamic exchange in which law shapes the routines of everyday life and in turn is informed and transformed by everyday categories and routines (Yngvesson 1988; Ewick \& Silbey 1992). Without being specifically invoked or even explicitly considered, law may shape everyday thoughts and actions (Engel \& Munger 1996). It may change the way social interactions take place and are perceived without any explicit awareness of the legal underpinnings of this change. Finally, legal recognition and validation of rights communicate normative judgments about the underlying rights themselves and those who claim them (Williams 1991).

When the public face of adjudication shows primarily employer wins, judges and citizens may come to believe that the dubious claims reflected in published opinions accurately depict the underlying nature of all rights claims under a statute and that most claims lack merit. Citizens may conclude that the underlying problem the statute addresses no longer exists or never existed to begin with. This erosion of the moral force of the statute may in turn erode individuals' willingness to mobilize its protections and to risk social disapproval by bringing such a claim.

This discussion shows how published judicial opinions can encourage or inhibit social change through feedback effects. If the litigation process systematically excludes information about both violations and successful mobilization of rights from the judicial determination of rights, this information has only limited opportunity to affect future mobilization, compliance, and negotiation. Over time, this dynamic may curtail the capacity of the law to produce social change by inhibiting mobilization, requiring little for compliance, reducing the settlements negotiated in the shadow of the law, and limiting the favorable legal authority 
available to employees in future disputes and thus curtailing their likelihood of success. Once this process restricts the scope and meaning of statutory rights, the law's capacity to reshape social relations may become similarly confined.

It is important to consider not only courts' dispute resolution function but also their lawmaking role and to theorize the relationship between the two. In his article Against Settlement, Fiss (1984:1085) argues that the duty of the courts

is not to maximize the ends of private parties, nor simply to secure the peace, but to explicate and give force to the values embodied in authoritative text such as the Constitution and statutes: to interpret those values and bring reality into accord with them. This duty is not discharged when parties settle.

Fiss treats the common law as a public good, socially owned, and with profound social meaning. He takes one position in a larger debate about whether courts are dispute resolution institutions for private disputes or whether their opinions serve wider public and social functions (Chayes 1976). If dispute resolution were the only objective, however, a simple declaration of winner and loser by the courts would suffice. Courts go beyond simply declaring the victor and produce legal opinions because opinions both justify a decision and reinforce the legitimacy and authority of courts (Bourdieu 1987).

Traditional conceptions of the rule of law presume that judicial decisions have meaning beyond the resolution of individual disputes. Judicial opinions make the law public, prospective, and clear so that citizens may know and understand the rules they are meant to obey (Fuller 1964). Opinions in individual cases state rules in general terms in part because universally and generally applied laws command authority (Unger 1976:69). The doctrine of stare decisis maintains the generality, stability, and consistency of courts' opinions, opinions that create rules to be applied in future cases and beyond the confines of an individual dispute. Thus, the legitimacy of the rule of law requires that the role of courts be more than just the resolution of individual disputes (Shapiro 1981:25-26). Court-created law enjoys this legitimacy in part because it possesses the institutional qualities of the rule of law. ${ }^{42}$

Interpreting statutory rights presents an example of courts' public law role because statutory rights reflect public norms and goals (Silbey \& Sarat 1989). Rights promise to harness the legitimacy and authority of the rule of law to impose meaningful remedies against the powerful (see Hendley 1996:14). Indeed, social change through statutory rights seems possible because of the ideal of the rule of law: a society governed not by the arbitrary

42 It is appropriate to acknowledge here that the rule of law is a notoriously contested concept and that this description may be useful only for this limited discussion. 
exercise of power but by a rational system of rules that claim legitimacy and authority (Weber 1954). Rights litigation seems to be an attractive avenue for social change because rights provide democratic access to courts' lawmaking process as well as the instrumental and constitutive power of law (Zemans 1983).

Scholars have recognized the public significance that the resolution of landmark cases may carry (Chayes 1976). Even in an ordinary case, however, more is at stake than resolution of an individual dispute. Individual disputes form the building blocks of a system of common-law precedent through which courts explain and interpret the law. Judicial opinions fill gaps in legislation by applying the law to a particular case (Hart 1961), and winning a legal decision influences the subsequent development of law. Settlement and trial even in ordinary cases remove a dispute from courts' interpretation of the law and separate the dispute resolution function of courts from their lawmaking role.

The influence of adjudication beyond the outcome in an individual dispute may be particularly important for statutory rights with normative objectives. The paradox of losing by winning, however, suggests that the litigation process may hamstring law's capacity for social change by focusing published adjudication on the weaker claims. The institutional characteristics of the rule of law then extend published judicial opinions through the system of interpretation and precedent while allowing settlement and unpublished dispositions to drop from sight. The invisibility of at least some attempts to claim the norms expressed in the statute affects the content of the law and consequently all those who order their relationships according to that law.

Perceptions of fairness and the ultimate legitimacy of the rule of law flow in part from courts' procedural protections and process (Friedman 1975:112-14; Tyler 1990). The procedural characteristics of the rule of law that seem to constitute a fair and impartial system of justice, however, are safeguards against historical forms of the arbitrary exercise of power, such as the whim of the king, not the more evolutionary influences that may undermine law's impartiality. Procedure may ensure equal access to courts to enforce the laws and to resolve disputes. It does not, however, ensure that all have equal access to courts as institutions of law creation. Even where the courts remain neutral as to outcome, the rule-making opportunities in the litigation process may nevertheless produce interpretations of individual rights that favor repeat players. Procedural protections locate justice and fairness in the equal ability of parties to present their positions and influence the outcomes of their cases, in short, the opportunity to be heard. The paradox of losing by winning suggests that for one-shot players claiming individual rights, success comes at the price of silence in the historical record of the common law. Thus, once again, the "haves" come out ahead. 


\section{References}

ABA Commission on Mental and Physical Disability Law (1998) "Study Finds Employers Win Most ADA Title I Judicial and Administrative Complaints," Mental \& Physical Disabilities Law Reporter, May-June, p. 403.

Black, Donald (1973) "The Mobilization of Law," 2 J. of Legal Studies 125-49.

Bourdieu, Pierre (1987) "The Force of Law: Toward a Sociology of the Juridical Field," 38 Hastings Law J. 805-53.

Bumiller, Kristin (1988) The Civil Rights Society. Baltimore: Johns Hopkins Univ. Press.

Bureau of National Affairs (1998) "Department of Labor Summary of Outreach, Compliance Activity under the 1993 Family and Medical Leave Act," Daily Labor Report, p. E1.

Burstein, Paul (1991) "Legal Mobilization as a Social Movement Tactic: The Struggle for Equal Employment Opportunity," 96 American J. of Sociology 1201-25.

Burstein, Paul, \& Kathleen Monaghan (1986) "Equal Employment Opportunity and the Mobilization of Law," 20 Law E Society Rev. 355-88.

Chayes, Abram (1976) "The Role of the Judge in Public Law Litigation," 89 Harvard Law Rev. 1281-1316.

Cooter, Robert, \& Lewis Kornhauser (1980) "Can Litigation Improve the Law without the Help of Judges?" $9 \mathrm{~J}$. of Legal Studies 139-63.

Cooter, Robert D. (1996) "Decentralized Law for a Complex Economy: The Structural Approach to Adjudicating the New Law Merchant," 144 Univ. of Pennsylvania Law Rev. 1643-96.

Edelman, Lauren B., Howard S. Erlanger, \& John Lande (1993) "Internal Dispute Resolution: The Transformation of Civil Rights in the Workplace," 27 Law E Society Rev. 497-534.

Ellickson, Robert C. (1991) Order without Law: How Neighbors Settle Disputes. Cambridge: Harvard Univ. Press.

Engel, David M., \& Frank W. Munger (1996) "Rights, Remembrance, and the Reconciliation of Difference," 30 Law E Society Rev. 7-53.

Erlanger, Howard S., Elizabeth Chambliss, \& Marygold S. Melli (1987) "Participation and Flexibility in Informal Processes: Cautions from the Divorce Context," 21 Law ${ }^{\circ}$ Society Rev. 585-604.

Ewick, Patricia, \& Susan Silbey (1992) "Conformity, Contestation, and Resistance: An Account of Legal Consciousness," 26 New England Law Rev. $731-49$.

Felstiner, William L. F., Richard L. Abel, \& Austin Sarat (1981) "The Emergence and Transformation of Disputes: Naming, Blaming, Claiming . . ," 15 Law Eo Society Rev. 631-54.

Fiss, Owen M. (1984) “Against Settlement," 93 Yale Law J. 1073-90.

Flaherty, Kelly, \& Emily Heller (1998) "Workers Face Tough Odds in Disability Suits, ABA Study Finds," Fulton County Daily Report, 30 June. Available on LEXIS LEGNEW library, ALLNWS file.

Friedman, Lawrence M. (1975) The Legal System: A Social Science Perspective. New York: Russell Sage Foundation.

Fuller, Lon L. (1964) The Morality of Law. New Haven, CT: Yale Univ. Press.

Galanter, Marc (1974). "Why the "Haves "Come Out Ahead: Speculations on the Limits of Legal Change," 9 Law $\mathcal{E}^{2}$ Society Rev. 95-160. (1975) "Afterword: Explaining Litigation," 9 Law E Society Rev. 347-68. (1983) "The Radiating Effects of Courts," in K. Boyum \& L. Mather, eds., Empirical Theories about Courts. New York: Longman.

Gross, Samuel R., \& Kent D. Syverud (1991) "Getting to No: A Study of Settlement Negotiations and the Selection of Cases for Trial," 90 Michigan Law Rev. 319-93. 
Hadfield, Gillian K. (1992) "Bias in the Evolution of Legal Rules," 80 Georgetown Law J. 583-616.

Handler, Joel F. (1978) Social Movements and the Legal System: A Theory of Law Reform and Social Change. New York: Academic Press.

Hart, H. L. A. (1961) The Concept of Law. Oxford: Clarendon Press.

Hendley, Kathryn (1996) Trying to Make Law Matter: Legal Reform and Labor Law in the Soviet Union. Ann Arbor: Univ. of Michigan Press.

Hirschman, Albert O. (1970) Exit, Voice, and Loyalty: Responses to Decline in Firms, Organizations, and States. Cambridge: Harvard Univ. Press.

Holmes, Oliver Wendell (1923) The Common Law. Boston: Little, Brown.

Judicial Conference of the United States (1995) Report of the Proceedings of the Judicial Conference of the United States. Washington, DC: Administrative Office of the United States Courts.

Kairys, David (1982) The Politics of Law: A Progressive Critique. New York: Pantheon Books.

Kelly, Erin, \& Frank Dobbin (1999) "Civil Rights Law at Work: Sex Discrimination and the Rise of Maternity Leave Policies," 105 American J. of Sociology 455-92.

Kritzer, Herbert M. (1986) "Adjudication to Settlement: Shading in the Gray," 70 Judicature 161-65.

Landes, William M., \& Richard A. Posner (1979) "Adjudication as a Private Good," $8 \mathrm{~J}$. of Legal Studies 235-84.

Macaulay, Stewart (1963) "Non-Contractual Relations in Business: A Preliminary Study," 28 American Sociological Rev. 55-67.

Maccoby, Eleanor, \& Robert Mnookin (1990) Dividing the Child. Cambridge: Harvard Univ. Press.

McCann, Michael (1994) Rights at Work: Pay Equity Reform and the Politics of Legal Mobilization. Chicago: Univ. of Chicago Press.

Miller, Richard E., \& Austin Sarat (1981). "Grievances, Claims, and Disputes: Assessing the Adversary Culture," 15 Law E Society Rev. 525-65.

Mnookin, Robert, \& L. Kornhauser (1979) "Bargaining in the Shadow of the Law: The Case of Divorce," 88 Yale Law J. 950-97.

Olson, Susan M. (1992) "Studying Federal District Courts through Published Cases: A Research Note," 15 Justice System J. 782-800.

Priest, George L., \& Benjamin Klein (1984) "The Selection of Disputes for Litigation," $13 \mathrm{~J}$. of Legal Studies 1-55.

Purcell, Daniel (1997) "The Public Right to Precedent: A Theory and Rejection of Vacatur," 85 California Law Rev. 867-917.

Rosenberg, Gerald N. (1991) The Hollow Hope: Can Courts Bring about Social Change? Chicago: Univ. of Chicago Press.

Rubin, Edward, \& Malcolm Feeley (1996) "Creating Legal Doctrine," 69 Southern California Law Rev. 1989-2037.

Sarat, Austin, \& Thomas S. Kearns (1993). "Beyond the Great Divide: Forms of Legal Scholarship and Everyday Life," in A. Sarat and T. S. Kearns, eds., Law in Everyday Life. Ann Arbor: Univ. of Michigan Press.

Scheingold, Stuart A. (1974) The Politics of Rights. New Haven, CT: Yale Univ. Press.

Segal, Jeffrey A., \& Harold J. Spaeth (1996) "The Influence of Stare Decisis on the Votes of the United States Supreme Court Justices," 40 American J. of Political Science 971-1003.

Siegelman, Peter, \& John J. Donohue (1990) "Studying the Iceberg from Its Tip: A Comparison of Published and Unpublished Employment Discrimination Cases," 24 Law E' Society Rev. 1133-70.

Shapiro, Martin (1981) Courts: A Comparative and Political Analysis. Chicago: Univ. of Chicago Press. 
Silbey, Susan, \& Austin Sarat (1989). "Dispute Processing in Law and Legal Scholarship: From Institutional Critique to the Reconstruction of the Juridical Subject," 66 Denver Univ. Law Rev. 437.

Slavitt, Howard (1995) "Selling the Integrity of the System of Precedent: Selective Publication, Depublication, and Vacatur," 30 Harvard Civil Rights-Civil Liberties Law Rev. 109-42.

Songer, Donald R., \& Reginald S. Sheehan (1992) "Who Wins on Appeal? Upperdogs and Underdogs in the United States Courts of Appeals," 36 American J. of Political Science 235-58.

Songer, Donald R., Jeffrey A. Segal, \& Charles M. Cameron (1994) "The Hierarchy of Justice: Testing a Principle-Agent Model of Supreme Court-Circuit Court Interactions," 38 American J. of Political Science 673-96.

Songer, Donald R., Danna Smith, \& Reginald S. Sheehan (1989) "Nonpublication in the Eleventh Circuit: An Empirical Analysis," 16 Florida State Univ. Law Rev. 963-84.

Spaeth, Harold J., \& Jeffrey A. Segal (1999) Majority Rule or Minority Will. Cambridge: Cambridge Univ. Press.

Trubek, David M., Austin Sarat, William L. F. Felstiner, Herbert M. Kritzer, \& Joel B. Grossman (1983) "The Costs of Ordinary Litigation," 31 UCLA Law Rev. 72-127.

Tyler, Tom (1990) Why People Obey the Law. New Haven, CT: Yale Univ. Press.

Unger, Roberto (1976) Law in Modern Society: Toward a Criticism of Social Theory. New York: Free Press.

U.S. Bureau of the Census (1997) Statistical Abstract of the United States: 1997. 117 th ed. Washington, DC: GPO.

Walsh, David J. (1997) "On the Meaning and Pattern of Legal Citations: Evidence from State Wrongful Discharge Precedent Cases," 31 Law $\mathcal{E}$ Society Rev. 337-60.

Wanner, Craig (1975) "The Public Ordering of Private Relations Part Two: Winning Civil Court Cases," 9 Law E Society Rev. 293-306.

Weber, Max (1954) On Law in Economy and Society. Edited by Max Rheinstein. Cambridge: Harvard Univ. Press.

Wheeler, Stanton, Bliss Cartwright, Robert A. Kagan, \& Lawrence M. Friedman (1987) 'Do the 'Haves' Come Out Ahead? Winning and Losing in State Supreme Courts, 1870-1970," 21 Law E Society Rev. 403-45.

Williams, Patricia (1991) The Alchemy of Race and Rights. Cambridge: Harvard Univ. Press.

Yngvesson, Barbara (1988) "Making Law at the Doorway: The Clerk, the Court, and the Construction of Community in a New England Town," 22 Law $\mathcal{E}^{\circ}$ Society Rev. 409-48.

Zemans, Frances Kahn (1983) "Legal Mobilization: The Neglected Role of the Law in the Political System," 77 American Political Science Rev. 690-703.

\section{Cases Cited}

Bauer v. Varity Dayton-Walther Corp., 118 F.3d 1109 (6th Cir. 1997).

Benevides v. Jackson Nat'l Life Ins. Co., 820 F. Supp. 1284 (D. Colo. 1993).

Cahill v. Liberty Mutual Ins. Co., 80 F.3d 336 (9th Cir. 1996).

Conley v. Gibson, 355 U.S. 41 (1957).

Coopers \& Lybrand v. Livesay, 437 U.S. ' 463 (1978).

Diaz v. Fort Wayne Foundry Corp., 131 F.3d 711 (7th Cir. 1997).

Eastus v. Blue Bell Creameries, L.P., 97 F.3d 100 (5th Cir. 1996).

Evans v. Jeff D., 475 U.S. 717 (1985).

Foman v. Davis, 371 U.S. 178 (1962).

Kariotis v. Navistar Int'l Transp. Corp., 131 F.3d 672 (7th Cir. 1997).

Manuel v. Westlake Polymers Corp., 66 F.3d 758 (5th Cir. 1995).

Murphy v. FDIC, 38 F.3d 1490 (9th Cir. 1994).

Taxman v. Board of Educ., 91 F.3d 1547 (3rd Cir. 1996). 
U.S. Bancorp Mortgage Co. v. Bonner Mall Partnership, 513 U.S. 18 (1994). Victorelli v. Shadyside Hosp., 128 F.3d 183 (3rd Cir. 1997).

Warren v. City of Carlsbad, 58 F.3d 439 (9th Cir. 1995).

\section{Statutes Cited}

28 U.S.C. 1292 (b)

28 U.S.C. 1441 et seq.

29 U.S.C. 2611 (4).

29 U.S.C. $2612(\mathrm{a})$.

29 U.S.C. 2614.

29 U.S.C. 2617.

Fed. R. Civ. P. 12(b).

Fed. R. Civ. P. 15.

29 C.F.R. 825.220 (c). 